\title{
PENGARUH MODEL DISCOVERY LEARNING BERBANTUAN ALAT PRAKTIKUM USAHA DAN ENERGI TERHADAP PENGUASAAN KONSEP FISIKA PESERTA DIDIK
}

\section{THE EFFECT OF PRACTICUM TOOLS WORK AND ENERGY ASSISTED DISCOVERY LEARNING MODEL FOR STUDENTS PHYSIC CONCEPT MASTERY}

\author{
Maulida Turrahmah $^{1 *}$, Susilawati ${ }^{1}$, Muh. Makhrus ${ }^{2}$ \\ ${ }^{1}$ Program Studi Pendidikan IPA Universitas Mataram, Indonesia \\ ${ }^{2}$ Program Studi Pendidikan Fisika, Jurusan Pendidikan MIPA, FKIP, Universitas Mataram, Indonesia \\ *Email: maulidatulrahmahindra@gmail.com; susilawatihambali@unram.ac.id
}

Diterima: 25 Agustus 2019. Disetujui: 20 Septemebr 2019. Dipublikasikan: 30 September 2019

\begin{abstract}
Abstrak. Penelitian ini bertujuan untuk mencari pengaruh model Discovery Learning berbantuan alat praktikum usaha dan energi terhadap penguasaan konsep fisika peserta didik kelas X SMAN 1 Gunungsari tahun pelajaran 2018/2019. Jenis penelitian ini adalah quasi experiment dengan desain penelitian posttest only control group design. Pengambilan sampel dalam penelitian ini menggunakan teknik simple random sampling, sehingga diperoleh kelas X MIA 2 sebagai kelas eksperimen sebanyak 24 orang dan kelas X MIA 1 sebagai kelas kontrol sebanyak 27 orang. Kelas eksperimen diberikan perlakuan dengan menggunakan model Discovery Learning berbantuan alat praktikum usaha dan energi sedangkan kelas kontrol menggunakan pembelajaran Konvensional. Data penguasaan konsep diperoleh dengan menggunakan tes uraian sebanyak 10 soal yang sudah diuji validitas, reliabilitas, tingkat kesukaran dan daya pembeda soal. Hasil tes akhir penguasaan konsep diperoleh nilai rata-rata kelas eksperimen sebesar 77,55 dan nilai rata-rata kelas kontrol sebesar 73,19. Hipotesis penelitian diuji menggunakan uji t polled varians dengan taraf signifikansi 5\% dan diperoleh hasil $t_{\text {hitung }}$ sebesar 2,12 dan $t_{\text {tabel }}$ sebesar 2,02 sehingga nilai $t_{\text {hitung }}$ lebih besar dari $t_{\text {tabel }}$. Berdasarkan hasil tersebut dapat disimpulkan bahwa terdapat pengaruh model discovery learning berbantuan alat praktikum usaha dan energi terhadap penguasaan konsep fisika peserta didik.
\end{abstract}

Kata Kunci : Penguasaan Konsep, Discovery Learning, Alat Praktikum

\begin{abstract}
This research was aim to search the effect of practicum tools work and energy assisted Discovery Learning model for students physic concept mastery class X SMAN 1 Gunungsari. This type of research was quasi experiment with posttest only control group design. Sampling in this research uses simple random sampling technique, so that the X MIA 2 class as the experimental and the X MIA 1 clas as the control class. The experimental class was given treatment using the practicum tools work and energy assisted Discovery Learning model while the control class uses Conventional learning. Concept mastery data was obtained by using essay test as many as 10 questions. The results of posttest concept mastery obtained by the average value of the experimental class is 77.55 and the average value of the control class is 73.19. Hypothesis testing using polled varians t-test with $5 \%$ of significance level and the results of $t_{\text {count }}$ was 2.12 and $t_{\text {table }}$ was 2.02 so that the value $t_{\text {count }}$ more larger than $t_{\text {table }}$. Based on these results it be found concluded the effect of practicum tools work and energy assisted Discovery Learning model for studnts physic concept mastery.
\end{abstract}

Keywords : Concept Mastery, Discovery Learning, Practicum Tools

\section{PENDAHULUAN}

Belajar adalah suatu proses perubahan tingkah laku seseorang secara keseluruhan yang disebabkan karena adanya interaksi dengan lingkungannya [1]. IPA atau sains merupakan mata pelajaran yang wajib diperoleh oleh peserta didik, di mana sains didefinisikan sebagai ilmu yang mempelajari tentang sebab akibat peristiwa-peristiwa yang terjadi di alam. Sains juga dapat diartikan sebagai kumpulan pengetahuan yang sistematis dari gejala-gejala alam [2]. Sains tidak hanya terdiri dari kumpulan yang terisolasi satu dengan lainnya melainkan kumpulan ilmu pengetahuan yang terorganisasi secara sistematis [3].

Fisika mempelajari gejala-gejala alam melalui serangkaian proses ilmiah yang dilandasi oleh sikap ilmiah dan hasilnya dituangkan dalam wujud produk ilmiah yang tersusun atas komponenkomponen penting berupa fakta, konsep, generalisasi, prinsip, teori dan hukum-hukum fisika yang berlaku secara universal [4].

Studi pendahuluan yang dilakukan saat proses pembelajaran melalui observasi dan wawancara dengan guru fisika dan peserta didik kelas X MIA SMAN 1 Gunungsari, diperoleh 
beberapa permasalahan yang dihadapi pada saat proses pembelajaran fisika diantaranya adalah sebagai berikut: 1) peserta didik kurang berminat mengikuti pembelajaran fisika, 2) praktikum pada proses pembelajaran fisika sangat jarang dilakukan, 3) laboratorium fisika yang seharusnya digunakan sebagai tempat praktikum seringkali dialihfungsikan. Permasalahan-permasalahan tersebut menyebabkan pola pikir peserta didik terhadap pembelajaran fisika, di mana peserta didik beranggapan bahwa pembelajaran yang sudah dilakukan tidak bermakna dan tidak bermanfaat, karena tidak ada kaitan antara pembelajaran yang sudah dilakukan dengan peristiwa yang terjadi dalam kehidupan nyata di sekitarnya. Pembelajran fisika yang dianggap tidak bermakna dan tidak bermanfaat inilah yang menjadi faktor pemicu hasil belajar fisika peserta didik masih rendah. Hasil belajar fisika peserta didik yang rendah merupakan indikator bahwa penguasaan peserta didik terhadap konsep dan prinsip fisika rendah. Bloom mengemukakan bahwa penguasaan konsep merupakan suatu kemampuan menangkap pengertian-pengertian seperti mampu mengungkapkan suatu materi yang disajikan ke dalam bentuk yang lebih dipahami, mampu memberikan interpretasi dan mampu mengaplikasikannya [5]. Konsep dapat diartikan sebagai buah pemikiran seseorang atau kelompok orang yang dinyatakan dalam definisi sehingga melahirkan produk pengetahuan meliputi prinsip, hukum dan teori [6]. Konsep diperoleh dari fakta, peristiwa, pengalaman melalui generalisasi dan berpikir abstrak, kegunaan konsep untuk menjelaskan dan meramalkan oleh karena itu pembelajaran fisika harusnya disajikan dengan model pembelajaran yang dapat meningkatkan penguasaan konsep fisika peserta didik serta menyajikan pembelajaran fisika dengan berbantuan alat praktikum yang tersedia di laboratorium fisika sehingga materi yang akan disampaikan dapat dikaitkan dengan kehidupan nyata yaitu dengan melalui kegiatan praktikum [7].

Teori Burner menyatakan bahwa dengan menggunakan model Discovery Learnig peserta didik dalam proses pembelajaran lebih aktif dalam membangun konsep-konsep dan prinsip-prinsip [8]. Model Discovery Learning merupakan suatu model pembelajaran yang melibatkan seluruh kemampuan peserta didik secara maksimal untuk dapat mencari dan menemukan sesuatu baik benda, manusia, atau peristiwa secara sistematis, kritis, logis dan analitis sehingga dengan penuh percaya diri peserta didik dapat merumuskan sendiri penemuanya [9].

\section{METODE PENELITIAN}

Penelitian ini merupakan penelitian kuasi eksperimen, dengan desain penelitian posttest only control group design. Proses pembelajaran menggunakan model Discovery Learning berbantuan alat praktikum usaha dan energi pada kelas eksperimen dan pembelajaran konvensional pada kelas kontrol. Instrumen penelitian menggunakan tes uraian pada materi usaha dan energi dengan subjek penelitian adalah peserta didik kelas X MIA di SMAN 1 Gunungsari tahun pelajaran 2018/2019. Kelas X MIA 2 sebanyak 24 orang sebagai kelas eksperimen dan kelas X MIA 1 sebanyak 27 orang sebagai kelas kontrol dengan teknik pengambilan sampel yaitu simple random sampling.

Instrumen yang digunakan dalam penelitian ini berupa lembar penilaian ranah afektif dan lembar penilaian ranah psikomotor. Lembar penilaian ranah afektif berupa lembar observasi terhadap sikap peserta didik selama proses pembelajaran dan lembar penilaian ranah psikomotor berupa lembar observasi terhadap keterampilan peserta didik selama proses pembelajaran di mana penilaian dengan menggunakan lembar penilaian ranah afektif dan psikomotor akan disesuaikan dengan rubrik penilaian yang sudah dibuat. Data hasil penguasaan konsep diuji prasyarat berupa uji normalitas dan uji homogenitas. Kemudian dilanjutkan dengan uji hipotesis menggunakan uji t polled varians.

\section{HASIL DAN PEMBAHASAN}

Penelitian dimulai dengan memberikan perlakuan yang berbeda pada kedua kelas, saat diberikan perlakuan maka dilakukan penilaian pada ranah afektif dan penilaian pada ranah psikomotor kemudian diberikan tes akhir untuk menilai penguasaan konsep pada ranah kognitif. Hasil penelitian menunjukkan bahwa penguasaan konsep fisika peserta didik pada kelas eksperimen lebih tinggi dari pada kelas kontrol, hal ini ditunjukkan dengan nilai pada ranah afektif dan nilai pada ranah psikomotor saat proses pembelajaran serta nilai tes akhir penguasaan konsep pada ranah kognitif peserta didik kelas eksperimen lebih tinggi dari pada kelas kontrol. Berikut nilai pada ranah afektif peserta didik kelas eksperimen dan kelas kontrol disajikan pada Gambar 1.

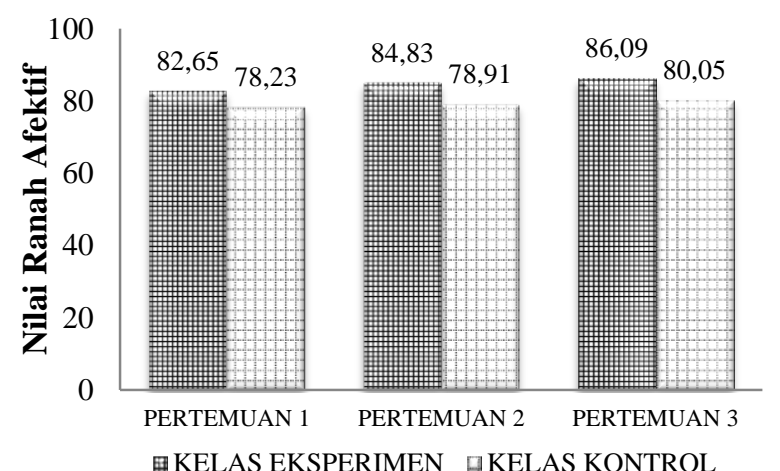

Gambar 1. Nilai Rata-Rata Penilaian pada Ranah Afektif 
Gambar 1 menunjukkan bahwa peserta didik pada kelas eksperimen memiliki nilai pada ranah afektif saat proses pembelajaran lebih tinggi dibandingkan kelas kontrol pada setiap pertemuan. Rangkaian pembelajaran yang diterapkan pada kelas eksperimen menunjukkan bahwa terdapat proses pembelajaran dengan menggunakan model Discovery Learning dapat melatih peserta didik dalam bersikap. Hal inilah yang menyebabkan nilai sikap peserta didik pada kelas eksperimen yang menerapkan model Discovery Learning lebih tinggi dari kelas kontrol yang menerapkan pembelajaran konvensional. Azwar [10] menyatakan bahwa sikap tidak hanya merupakan aspek mental semata, melainkan mencangkup pula aspek respon fisik.Jadi sikap ini harus ada kekompakan antara mental dan fisik secara serempak. Jika mental saja yang dimunculkan, maka belum tampak secara jelas sikap seseorang yang ditunjukkanya.

Berikut nilai pada ranah psikomotor peserta didik kelas eksperimen dan kelas kontrol disajikan pada Gambar 2.

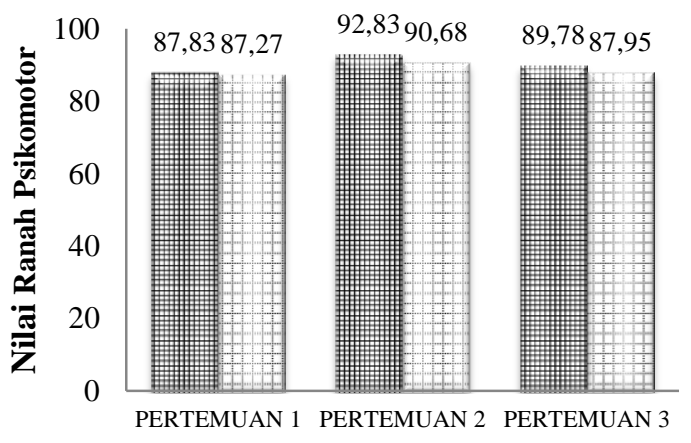

घ MELAS EKSPERIMEN 口KELAS KONTROL

Gambar 2. Nilai Rata-Rata Penilaian pada Ranah Psikomotor

Berdasarkan Gambar 2 terlihat bahwa peserta didik pada kelas eksperimen memiliki nilai keterampilan pada ranah psikomotor saat proses pembelajaran yaitu dengan praktikum menggunakan alat praktikum usaha dan energi yang lebih tinggi dibandingkan kelas kontrol pada setiap pertemuan. Penilaian keterampilan pada kelas eksperimen dan kelas kontrol memiliki selisih nilai yang tidak jauh berbeda karena kedua kelas melakukan kegiatan praktikum menggunakan alat praktikum usaha dan energi, dimana saat kegiatan praktikum kedua kelas dilatih untuk memiliki keterampilan yang baik. Usman dan Setiawati [11] mengemukakan bahwa keterampilan proses merupakan keterampilan yang mengarah kepada pembangunan kemampuan mental, fisik, dan sosial yang mendasar sebagai penggerak kemampuan yang lebih tinggi dalam diri individu.

Berikut hasil penguasaan konsep pada kelas eksperimen dan kelas kontrol disajikan pada Gambar 3.

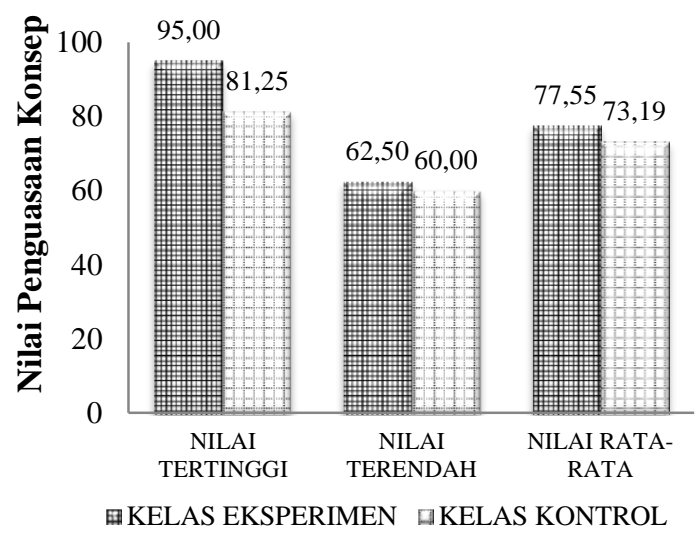

Gambar 3. Perbandingan Nilai Penguasaan Konsep Fisika Peserta Didik

Berdasarkan Gambar 3. nilai tertinggi untuk kelas eksperimen yaitu 95,00 dan nilai tertinggi untuk kelas kontrol yaitu 81,25. Sedangkan nilai terendah untuk kelas eksperimen adalah 62,50 dan nilai terendah untuk kelas kontrol yaitu 60,00. Nilai rata-rata kelas eksperimen yaitu 77,55 dan nilai ratarata kelas kontrol yaitu 73,19. Nilai rata-rata untuk kelas eksperimen sudah mencapai nilai KKM fisika sebesar 75 di SMAN 1 Gunungsari, sedangkan nilai rata-rata untuk kelas kontrol belum mencapai nilai KKM fisika sebesar 75 di SMAN 1 Gunungsari. Perbedaan tersebut karena model pembelajaran Discovery Learning memberikan pengaruh pada penguasaan konsep fisika peserta didik.

Analisis selanjutnya adalah analisis secara statistik di mana analisis ini dilakukan untuk pembuktian lebih jauh, maka dilakukan uji prasyarat analisis data yaitu dengan melakukan uji normalitas dan uji homogenitas dengan data tes akhir fisika peserta didik. Berdasarkan hasil tes akhir didapatkan bahwa data terdistribusi normal dan homogen. Analisis selanjutnya yaitu dengan menggunakan uji t independen dengan menggunakan rumus polled varians dan didapatkan nilai t hitung yaitu 2,12 lebih besar dari t tabel yaitu 2,02 artinya terdapat pengaruh model Discovery Learning berbantuan alat praktikum usaha dan energi terhadap penguasaan konsep fisika peserta didik. Berdasarkan hasil ini, maka dapat dikatakan penelitian ini berhasil sesuai dengan tujuan yang diharapkan. Hasil tersebut didapatkan karena kelas eksperimen dengan menerapkan model Discovery Learning terdapat fase yang menghubungkan hasil praktikum dengan konsep yang sesuai dengan materi usaha dan energi dapat membangun penguasaan konsep yang lebih baik dari pada kelas kelas kontrol yang menerapkan pembelajaran konvensional. Hasil ini dibuktikan dengan nilai rata-rata penguasaan konsep fisika peserta didik pada kelas eksperimen lebih tinggi dibandingkan nilai rata-rata penguasaan konsep fisika pada kelas kontrol. Sejalan dengan hal ini Sani [12] mengemukakan bahwa, model Discovery 
Learning merupakan pembelajaran di mana guru dituntut untuk lebih kreatif dalam menciptakan kondisi belajar agar peserta didik lebih aktif menemukan sendiri pengetahuannya. Penelitian Simbolon dan Situmorang [13], menyatakan bahwa kelas yang diajarkan dengan model pembelajaran Discovery Learning, hasil belajarnya lebih tinggi dibandingkan dengan kelas yang tidak diajarkan dengan menggunakan model pembelajaran Discovery Learning. Putri [14], menyatakan bahwa kelas eksperimen yang diajarkan dengan model Discovery Learning, motivasi belajar dan hasil belajarnya lebih tinggi dibandingkan dengan kelas kontrol yang diajarkan dengan model pembelajaran konvensional. Nilai penguasaan konsep kelas eksperimen lebih tinggi dibandingkan dengan kelas kontrol, selain disebabkan karena penerapan model Discovery Learning juga disebabkan karena penggunaan alat praktikum usaha dan energi dalam pembelajaran. Alat praktikum usaha dan energi membantu peneliti dalam menyampaikan materi usaha dan energi menjadi lebih mudah yaitu dengan mengadakan kegiatan praktikum sehingga peserta didik lebih aktif menemukan sendiri fakta atau konsep fisika yang belum diketahui. Alat praktikum juga membuat peserta didik lebih memahami gejala fisika terkait dengan materi usaha dan energi karena praktikum yang dilakukan dengan menggunakan alat praktikum berkaitan dengan gejala fisika yang terjadi lingkungan disekitar. Selain kelas eksperimen kelas kontrol juga menggunakan alat praktikum hanya saja penggunaan alat praktikum pada kelas kontrol belum maksimal. Hal ini sejalan dengan pernyataan Wijaya [15] menyatakan bahwa pembelajaran fisika memiliki begitu banyak konsep-konsep sains yang bersifat fisik yang begitu sulit bagi peserta didik untuk dipahami secara teoritis sehingga diperlukan media pembelajaran untuk memahami konsepkonsep tersebut, salah satu media yang dapat digunakan adalah alat praktikum. Saputra [16] menyatakan bahwa praktikum adalah salah satu cara untuk mengasah kemampuan berfikir peserta didik dalam belajar fisika. Penggunaan alat praktikum ini efektif meningkatkan keterampilan berpikir kreatif peserta didik. Alternatif tercapainya keterampilan proses secara maksimal adalah dengan adanya media pembelajaran seperti alat praktikum. Penggunaan alat praktikum ini efektif meningkatkan dan melatih keterampilan proses peserta didik. Hasil belajar kelas eksperimen yang dalam pembelajarannya menggunakan alat praktikum lebih tinggi dibandingkan kelas kontrol yang menggunakan model pembelajaran konvensional [17-20].

\section{KESIMPULAN}

Berdasarkan hasil penelitian dan pembahasan dapat dibuat kesimpulan bahwa terdapat pengaruh model Discovery Learning berbantuan alat praktikum usaha dan energi terhadap penguasaan konsep fisika peserta didik kelas X SMAN 1 Gunungsari. Model Discovery Learning berbentuan alat praktikum dapat dijadikan alternatif pada pembelajaran fisika oleh guru dengan materi yang berbeda dan subjek penelitian yang lebih luas. Dalam penerapan model Discovery learning berbantuan alat praktikum diperlukan perencanaan dan persiapan yang matang agar pembelajaran dapat berjalan sesuai tujuan yang hendak dicapai. Waktu yang digunakan selama pelaksanaan pembelajaran harus digunakan secara efisien. Pembagian kelompok saat menerapkan model Discovery Learning menggunakan kelompok dengan anggota yang tidak terlalu banyak sehingga guru dapat membangkitkan keinginan peserta didik untuk bertanya megenai fakta atau masalah yang disajikan.

\section{UCAPAN TERIMAKASIH}

Terima kasih yang sebesar-besarnya penulis sampaikan kepada Ibu Dra. Susilawati, M.Si., Ph.D. selaku Dosen Pembimbing I. Bapak Dr. Muh. Makhrus, M.Pd. selaku Dosen Pembimbing II. Bapak kepala sekolah beserta guru-guru SMAN 1 Gunungsari.

\section{DAFTAR PUSTAKA}

[1] Kosasih, E. (2014). Strategi belajar dan pembelajaran Implementasi Kurikulum 2013. Bandung: Yrama Widya, 170.

[2] Gunawan, G., Harjono, A., \& Sutrio, S. (2017). Multimedia Interaktif dalam Pembelajaran Konsep Listrik bagi Calon Guru. Jurnal Pendidikan Fisika dan Teknologi, 1(1), 9-14.

[3] Makhrus, M., \& Hadiprayitno, G. (2013). Penerapan Perangkat Pembelajaran Fisika Berorientasi Pembelajaran IPA Terpadu Tipe Connected. Jurnal Pendidikan dan Pembelajaran (JPP), 19(2), 237-242.

[4] Sari, P. I., Gunawan, G., \& Harjono, A. (2017). Penggunaan Discovery Learning Berbantuan Laboratorium Virtual pada Penguasaan Konsep Fisika Siswa. Jurnal Pendidikan Fisika dan Teknologi, 2(4), 176182.

[5] Silaban, B. (2014). Hubungan antara penguasaan konsep fisika dan kreativitas dengan kemampuan memecahkan masalah pada materi pokok listrik statis. Jurnal Penelitian Bidang Pendidikan, 20(01), 65-75.

[6] Sugiana, I. N., Harjono, A., Sahidu, H., \& Gunawan, G. (2017). Pengaruh Model Pembelajaran Generatif Berbantuan Media Laboratorium Virtual Terhadap Penguasaan Konsep Fisika Siswa pada Materi Momentum 
dan Impuls. Jurnal Pendidikan Fisika dan Teknologi, 2(2), 61-65.

[7] Hermansyah, H., Gunawan, G., \& Harjono, A. (2017). Pengaruh Penggunaan Laboratoium Virtual Dalam Pembelajaran Inkuiri Terbimbing Terhadap Penguasaan Konsep Kalor Peserta Didik. Jurnal Pendidikan Fisika dan Teknologi, 3(2), 249-256.

[8] Priansa, D. J. (2017). Pengembangan Strategi dan Model Pembelajaran. Bandung: $C V$ Pustaka Setia.

[9] Lidiana, H., Gunawan, G., \& Taufik, M. (2018). Pengaruh Model Discovery Learning Berbantuan Media PhET Terhadap Hasil Belajar Fisika Peserta Didik Kelas XI SMAN 1 Kediri Tahun Ajaran 2017/2018. Jurnal Pendidikan Fisika dan Teknologi, 4(1), 33-39.

[10] Azwar, S. (2010). Sikap Manusia Teori dan Pengukurannya. Yogyakarta Pustaka Pelajar.

[11] Usman, U., \& Setiawati, L. (1993). Upaya optimalisasi kegiatan belajar mengajar. Bandung: Remaja Rosdakarya.

[12] Sani, R. A. (2014). Pembelajaran saintifik untuk implementasi kurikulum 2013.

[13] Sari, E. N., Ridlo, S., \& Utami, N. R. (2016). Pengaruh Model Pembelajaran Discovery Learning Dengan Mind Mapping Terhadap Hasil Belajar Siswa Pada Materi SEL di SMA. Unnes Science Education Journal, 5(3).

[14] Putri, R. H., Lesmono, A. D., \& Aristya, P. D. (2017). Pengaruh Model Discovery Learning Terhadap Motivasi Belajar dan Hasil Belajar Fisika Siswa MAN Bondowoso. Jurnal Pembelajaran Fisika, 6(2), 173-180.

[15] Wijaya, R. C., Damris, M., \& Kamid, K. (2014). Pengembangan Media Pembelajaran Fisika Projectile Launcher sebagai Alat Praktikum Fisika pada Materi Gerak Parabola Fisika Kelas XI IPA. Edu-Sains: Jurnal Pendidikan Matematika dan Ilmu Pengetahuan Alam Universitas Jember, 3(2).

[16] Saputra, O., Nurjannah, N., \& Mansyur, J. (2014). Pengaruh Problem-Based Learning Menggunakan Praktikum Alat Sederhana Terhadap Keterampilan Berpikir Kreatif Siswa SMA Negeri 7 Palu. JPFT (Jurnal Pendidikan Fisika Tadulako Online), 2(2). 3642.

[17] Widiastutik, K. (2014). Pengembangan Alat Praktikum Gelombang Stasioner untuk Melatihkan Keterampilan Proses Siswa SMA
Kelas XI. Inovasi Pendidikan Fisika, 3(2).201-207.

[18] Sani, L. N., Rahayu, S., \& Hikmawati, H. (2018). Pengaruh Model Pembelajaran Direct Instruction Dengan Media Macromedia Flash Terhadap Hasil Belajar Fisika Kelas XI SMAN 1 Kopang. Jurnal Pijar MIPA, 13(1), 13-18.

[19] Khaerunnisa, B. S., Kusmiyati, K., \& Ilhamdi, M. L. (2019). Analisis Tingkat Kesulitan Yang Dialami Peserta Didik Dalam Praktikum Biologi di SMA. Jurnal Pijar Mipa, 14(1), 23-28.

[20] Ningsyih, S., Junaidi, E., \& Al Idrus, S. W. (2016). Pengaruh Pembelajaran Praktikum Berbasis Inkuiri Terbimbing Terhadap Kemampuan Berpikir Kritis Dan Hasil Belajar Kimia Siswa. Jurnal Pijar Mipa, 11(1). 